Farkas, Ákos. "Szerb, Antal. 2017. Reflections in the Library: Selected Literary Essays 1926-1944 (ed. Zsuzsanna Varga, trans. Peter Sherwood). Cambridge, UK: Legenda. Studies in Comparative Literature 46. 132 pp."

Hungarian Cultural Studies. e-Journal of the American Hungarian Educators Association, Volume 10 (2017) DOI: 10.5195/ahea.2017.311

\title{
Szerb, Antal. 2017. Reflections in the Library: Selected Literary Essays 1926-1944 (ed. Zsuzsanna Varga, trans. Peter Sherwood). Cambridge, UK: Legenda. Studies in Comparative Literature 46. 132 pp.
}

\section{Reviewed by Ákos Farkas*", Eötvös Loránd University, Budapest}

Bearing the title "Gondolatok a könyvtárban," (translated into English as "Reflections in the Library") of a major philosophical poem by Mihály Vörösmarty, the collection subtitled Selected Literary Essays 1926-1944, skillfully translated from Hungarian by Peter Sherwood, edited with utmost circumspection by Zsuzsanna Varga, provided with a magisterial Introduction by Ágnes Péter and a foreword by Galin Tihanov, reveals much about its author, the novelist, scholar, and man of letters Antal Szerb and his mindset. Vörösmarty's national background, his concerns as a poet-thinker, and the period he represents were either shared or consistently revisited by Szerb, who in 1930 devoted a substantial study to Hungary's foremost Romantic poet.

The international array of Szerb's scholarship and views is well documented by the range of his writings included in the collection under review, with essays drawing the portraits of French, Spanish, German, Russian and - predominantly - English writers and poets. However, Szerb's abiding interest in world literature was coupled with an equally enduring commitment to his own country's literature and culture. His 1934 study titled A magyar irodalom története ['The History of Hungarian Literature'] bears witness to his conviction that any important links between Hungarian literature and Europe at large should always be duly represented, an obligation he formally undertook as part of the specifications of the grant that enabled him to complete his first major contribution to his country's literary scholarship. Although after this work - which is not represented in Reflections in the Library - the focus of his research became firmly focused on foreign-language literature, Szerb continued to oblige his Hungarian readers by drawing their attention to the interaction between Western and Hungarian literature whenever the occasion for that arose.

Whether initially published in the leading journals and magazines of the time, such as the liberal Nyugat ['West'] and its successor Magyar Csillag ['Hungarian Star'], or in the more conservative Uj Idők ['New Times'] and Minerva, or in his books such as the ground-breaking Hétköznapok és csodák ['The Everyday and the Miraculous'] and the authoritative A világirodalom története ['The History of World Literature'], Szerb's essays on world literature

*farkas.akos@btk.elte.hu

(cc) $\mathrm{Br}$

ULIS D-Serke
New articles in this journal are licensed under a Creative Commons Attribution 4.0 International License.

This journal is published by the University Library System of the University of Pittsburgh as part of its D-Scribe Digital Publishing Program and is cosponsored by the University of Pittsburgh Press 
Farkas, Ákos. "Szerb, Antal. 2017. Reflections in the Library: Selected Literary Essays 1926-1944 (ed. Zsuzsanna Varga, trans. Peter Sherwood). Cambridge, UK: Legenda. Studies in Comparative Literature 46.132 pp."

Hungarian Cultural Studies. e-Journal of the American Hungarian Educators Association, Volume 10 (2017) DOI: 10.5195/ahea.2017.311

selected for Reflections in the Library are all typical in that they abound in references to Hungarian authors such as Miklós Zrínyi, Ferenc Kölcsey, Sándor Petőfi, János Arany, Imre Madách, Endre Ady and Mihály Babits. Therefore his recurring allusions to Hungarian literature and culture can be expected even when he writes about Milton, Byron, Stefan George, Shelley or Katherine Mansfield. These asides invariably have more than marginal relevance to Szerb's train of thought. For example, he makes the insightful observation that "the rebirth of national cultures that derived from the Rousseauesque idea" covers the case of "the rebirth of Hungary," too (58). No less insightful is the analogy he draws between the abandonment of imitation for the sake of genuine self-expression in the development of both marginalized nations and subdued groups like women, as exemplified in the works of Hungarian poets György Bessenyei and Vörösmarty and in the prose works of British women writers George Eliot and Virginia Woolf.

And yet, whatever Hungarian undercurrents may be felt tugging at Szerb's observations and arguments in his essays in Reflections, Tihanov's remark in the Foreword on the international quality of "Szerb's account of Hungarian literature" is even more pertinent when it comes to Szerb's writings on world literature. If Szerb's History of Hungarian Literature is "demonstrably free of national bias," then in his essays on foreign writers it is even more obvious how far he "[left] behind the parochialism of the largely populist schemata" employed by the leading exponents of Hungarian criticism in the interwar period (ix). Szerb's perspective was decidedly all-European and informed by the most advanced theoretical approaches of his time: the Geistgeschichte of Wilhelm Dilthey and his followers (including the GermanHungarian Theodore Thienemann as well as Georg Lukács before his turn to Marxism), the socio-historical criticism of the academic critic János Horváth (co-editor of the scholarly journal Minerva), Freudian psychoanalysis, the cultural morphology of Oswald Spengler, and such early forms of mythological criticism as those promulgated by Jung's associate Carl Kerényi. Together and separately, these theories enabled Szerb, in the poet Attila József's resonant words, "the forces of production, without, [...] [to] reveal and the instincts, within, [to] unseal" ['tudomásul veszi [...] / a termelési eröket odakint s az / ösztönöket idebent'] (“Eszmélet," English translation by Anton N. Nyerges).

In addition to some temperamental affinities, it was Szerb's familiarity with Spengler's cyclical theory of the history of civilizations that attracted him to the (Pre-) Romantic pole of the Romantic-Realist dichotomy. Accordingly, Szerb's "heroes" are William Blake, whom he saw as a distinctly Blakean Milton, and the second generation of English Romantic poets Byron, Shelley and Keats, each meriting separate treatment in the first, large part of Reflections, titled "Essays on Romanticism." These mostly celebratory essays on Romantic poetry are then complemented by a more critical take on Rousseau. Influenced by Freudian notions, Szerb sees the preRomantic cult of regression into the childish and the primitive as symptomatic of a death wish that is far from balanced by a life-affirming drive. It is this aspect of Rousseau's influential Confessions, meaning its acceptance of Thanatos's dominance over Eros, that darkens the prospects of Romantic nostalgia. Completing the part dealing with "Romanticism" is yet another Byron-related essay titled "Don Juan's Secret," presenting Szerb's understanding of the culturally-coded changes in the history of love. Interestingly, Szerb's approach anticipates Michel Foucault's later emphasis on the radical otherness of the past, thus remaining relevant to cultural studies and discourses decades after his death. 
Farkas, Ákos. "Szerb, Antal. 2017. Reflections in the Library: Selected Literary Essays 1926-1944 (ed. Zsuzsanna Varga, trans. Peter Sherwood). Cambridge, UK: Legenda. Studies in Comparative Literature 46.132 pp."

Hungarian Cultural Studies. e-Journal of the American Hungarian Educators Association, Volume 10 (2017) DOI: 10.5195/ahea.2017.311

The second and last part of the volume is titled "Essays on Modernism" and it presents the reader with a Szerb whose ultimately Modernist views comprise seemingly irreconcilable opposites. The Romantic enthusiast vies here for ascendance with the order-seeking Classicist, the lover of individual freedom with the community-bound universalist, the lapsed but culturally loyal Catholic with the admirer of Classical Antiquity, and - last but not least - the guardian of venerable canons with the promoter of daring experimentation. The opening essay in this part, dealing with Stefan George, commends the German poet for his break with what Szerb believes to be the least attractive aspects of both eighteenth-century, Rousseauesque Romanticism and nineteenth-century progressivism: the narcissistic individualism of the former, the Godlessness of the latter and the escapism (sich fliehen) of both. What George is then said to leave behind is the self-deceptive yearning for another time and place, be it the exotic past or the evolutionary future. The present, "unencumbered with past or future," as Szerb quotes from Walter Pater, is where life "burns with a hard, gem-like flame" (76). Here Szerb emphatically asserts that the present he has in mind is not that of contemporary history but the here-and-now of the perfectly balanced individual and of the well-ordered, because divine, cosmos. Szerb claims, as much in the Spirit of Spengler's philosophy of crisis as in accordance with George's Antiquity-tinged Catholicism, that in terms of the nearness to God "the age in which we live is the sombrest of colours" (72).

That Szerb's brand of Modernism had much in common with Stefan George's detestation of modernity (reminiscent of T.S. Eliot's "immense panorama of futility and anarchy which is contemporary history," as described in "Ulysses, Order and Myth") is best demonstrated in the collection by Szerb's essay on Henrik Ibsen and even more so by the one devoted to G. K. Chesterton (Eliot qtd. in James Joyce: The Critical Heritage, vol. 1. p. 270). The essay about Ibsen, after assessing the general reader's changing responses to Ibsen's once immensely successful, but by the late 1920s disappointingly passé dramatic manifestos asserting the individual's right to freedom, as happens in Nora, or in a self-consciously poetic play weighed down by cumbersome symbolism as seen in The Wild Duck, offers the mature Szerb's evaluation of the Norwegian dramatist's surviving relevance. Ibsen's vaunted symbols, we are told, can yield some fresh and valuable psychological insights when read literally, rather than overinterpreted as endlessly complex literary figurations. This approach is clearly reminiscent of Szerb's insistence, in his essay about George, on the importance of concreteness, meaning the poet's and his critic's shared preference for the corporeal here-and-now over some vague pseudo-Romantic yearnings.

But preference of the here-and-there over the hazily romantic is only one part of the story: nothing is all that unambiguous for Szerb, for whom, as for his oft-quoted Goethe, alles ist gerade und alles ist ungerade ['everything is straight and everything is not straight at the same time'] $(124,125$ and 127). Nor does the essay about George or the one about Ibsen mark a radical break with Szerb's altogether favorable view of Romanticism. His pro-Romantic sympathies are manifested once again by the explanation he offers for the Norwegian dramatist's obsession with the theme of freedom. It is precisely Ibsen's inability to liberate himself from his crippling religious inheritance that Szerb believes to underlie that proto-modern playwright's lifelong struggle with his guilt-ridden conscience, his "hypertrophied self-consciousness" and 
Farkas, Ákos. "Szerb, Antal. 2017. Reflections in the Library: Selected Literary Essays 1926-1944 (ed. Zsuzsanna Varga, trans. Peter Sherwood). Cambridge, UK: Legenda. Studies in Comparative Literature 46.132 pp."

Hungarian Cultural Studies. e-Journal of the American Hungarian Educators Association, Volume 10 (2017) DOI: 10.5195/ahea.2017.311

compulsive introspection (87). And if the creative gain is outweighed by the psychic loss, as Szerb believes it did for Ibsen, then the Blakean message of "Damn braces: Bless relaxes" is as valid as ever.

It is, however, with his 1929 essay on Chesterton that Szerb's Romantic leanings, intermingled with his traditionalist tendencies, fully reassert themselves. Here the comic English novelist comes through as a master of the witty paradox who, unlike his paragons Oscar Wilde and G. B. Shaw, "took up arms against the proponents of progress" on behalf of tradition (99). Tradition here mostly means Chesterton's siding, "in the battle between sound good sense and Romanticism, with Romanticism, because the latter shows more sound good sense" (99). It needs to be noted that besides presenting Chesterton the essayist as a champion of such conventional values as religious faith, old-fashioned patriotism, and "the beleaguered social order" (99), Szerb emulated the Chestertonian example as a novelist, too. The case in point is Szerb's own curiously "postmodern" detective mystery A Pendragon legenda ['The Pendragon Legend'], for the spirit as well as for the narrative techniques of which he is indebted to Chesterton's Father Brown stories.

An article on Katherine Mansfield first published in Nyugat two years after the Chesterton essay attests to Szerb's lasting infatuation with contemporary English literature. This essay, referred to above regarding the analogy it draws between the cultural awakening of marginalized nations and the evolution of women's writing, is also significant for its awareness of what later came to be known as écriture feminine and for its acknowledgement of the irruptions of the "miraculous" into modern fiction (105), a topic that Szerb elaborates at length in his survey of the modern novel in Hétköznapok és csodák ['The Everyday and the Miraculous']. With its distinction between the "human and the demonic" strains in the Russian novel and its preference for the latter, the essay on Gogol following the one on Mansfield could be seen as thematically linking Szerb's Mansfield essay of 1931 to his Hétköznapok és csodák of 1936, if it were not for the much later time of publication of his Gogol essay. Published in Magyar Csillag in 1944 and thus following the two works that it seemingly connects, the Gogol essay appeared at a time when it must have taken no little courage to write or publish an appreciative essay in Hungary on its arch-enemy Russia or even on Russian culture.

Although preceding the Gogol essay by eight years in their first publication, the two essays concluding the volume of Reflections in the Library were rightly deemed to provide a perfect summary of Szerb's politics as well as his poetics. It is not only because the two authors standing at the respective centers of these two essays were believed by Szerb to be "the two greatest writers of the age" that each deserved a chapter of his or her own in Szerb's most elaborate theoretical overview of the modern European novel (123). The reason why Marcel Proust and Thomas Mann receive Szerb's most sustained attention in The Everyday and the Miraculous, where the seminally important James Joyce or Szerb's favorite Aldous Huxley are given less than half a chapter each, is because in their different ways both Proust and Mann stand for those humanistic values that Szerb had every reason to fear the loss of while working on this book some three years after Hitler's coming into power. In addition to the technical innovations of Proust's À la recherche du temps perdu, which Szerb duly notes, he also claims that this author's major achievement is his least likeable qualities, namely, his "hypersensitivity" bordering on the abnormal (119), his discovery of the by-then declining aristocracy for the "art 
Farkas, Ákos. "Szerb, Antal. 2017. Reflections in the Library: Selected Literary Essays 1926-1944 (ed. Zsuzsanna Varga, trans. Peter Sherwood). Cambridge, UK: Legenda. Studies in Comparative Literature 46.132 pp."

Hungarian Cultural Studies. e-Journal of the American Hungarian Educators Association, Volume 10 (2017) DOI: 10.5195/ahea.2017.311

of the novel" (121), and his rehabilitation of snobbery, "that powerful passion of the ancient regime" (122). It was the very fragility of such paraphernalia of a refined civilization that rendered them so dear to Szerb at a time when all that Proust and his art stood for were about to be swept away by a rising tide of banality and brutality.

As an undisputed master of the novel of ideas and as such a role-model of sorts for Szerb, himself a novelist-critic described by his first monographer György Poszler as "a scholar amongst writers and a writer amongst scholars" ("The Writer Who Believed in Miracles," 20), Thomas Mann could be expected to receive a significant place in The Everyday and the Miraculous. The German novelist's preoccupation with myth, a keen interest that involved him in regular correspondence with Szerb's friend Carl Kerényi, was another reason why the Hungarian critic devoted the closest possible attention to the writer of Joseph und seine Brüder. It is, after all, the weighty presence of myth in them for which the first installments of Mann's Biblical tetralogy were greeted as harbingers of the novel's turn to mythology and its "return to pure fiction, to wonders" (127). But Szerb's rare, because wholly unreserved, commendation of Thomas Mann's work had as much to do with the German novelist's relevance to Szerb's ethics as to his aesthetics. The greatest accolade that Szerb was willing to give anyone was earned by Mann with his "chilly humanism" (126), an ethos deriving "from an awareness of human dignity, and from the intellectual's serenity, tenderness, and horror of fighting, for it rises far, far above the passions that provoke human beings to commit bloody barbarities" (126). "This intellectbased morality," Szerb clarifies his point, "has been from Goethe onwards the greatest pride and achievement of the German spirit, and from this the new German world [...] has diverged the furthest" (126-127).

That it was not only the new Germany, Hitler's Germany, which Szerb believed to have departed from Goethe's and Mann's humanistic spirit is painfully clear to anyone familiar with the greatest disaster of modern history, the Holocaust, and the greatest shame of Szerb's own country of Hungary that allowed its faithful and exceptionally talented son, among hundreds of thousands of other Jews, to become a victim of the "bloody barbarities" foreseen in the Thomas Mann-essay. Antal Szerb, writer, scholar, critic, essayist and a Jewish-born convert to Catholicism, died in 1945 at the age of forty-four a brutally pointless death at the hands of some unknown henchmen of Hitler's Hungarian lackeys.

Reflections in the Library can be seen, among its other achievements, as a gesture of proclaiming, now to the English-speaking world, the lasting relevance of Szerb's legacy. It is to be hoped that this pioneer English-language selection of Antal Szerb's essays will be the first but not the last of its kind. Although Szerb's life's work was left unfinished, his contribution to the art of the essay is large and remarkable enough to merit a sequel. 